\title{
Síndrome de Compartimento Abdominal Durante Pinçamento por Via Endoscópica de Perfuração Intestinal Secundária à Colonoscopia *
}

\section{Abdominal Compartment Syndrome During Endoscopic Clamping of an Intestinal Perforation Secondary to Colonoscopy*}

\author{
Magda Lourenço Fernandes, TSA ${ }^{1}$, Kleber Costa de Castro Pires, TSA ${ }^{2}$, Paulo Henrique Baumgratz Chimelli ${ }^{3}$, \\ Márcia Rodrigues Neder Issa ${ }^{4}$
}

\section{RESUMO}

Fernandes ML, Pires KCC, Chimelli PHB, Issa MRN - Síndrome de Compartimento Abdominal Durante Pinçamento por Via Endoscópica de Perfuração Intestinal Secundária à Colonoscopia.

JUSTIFICATIVA E OBJETIVOS: A colonoscopia é um exame muito utilizado nos dias atuais para diagnóstico, tratamento e controle de doenças intestinais. A perfuração intestinal, embora rara, é a mais temida complicação deste exame. A correção da perfuração pode ser feita através do uso de clipes posicionados por via endoscópica. O objetivo deste relato de caso foi alertar os especialistas para a ocorrência e o tratamento de síndrome de compartimento abdominal durante pinçamento endoscópio de perfuração intestinal secundário à colonoscopia.

RELATO DO CASO: Paciente do sexo feminino, 60 anos, estado físico ASA II, submetida à colonoscopia sob sedação. Durante o exame constatou-se perfuração acidental do intestino e optou-se por tentar pinçar a perfuração por via endoscópica. A paciente evoluiu então com dor e distensão abdominal, pneumoperitônio, síndrome de compartimento abdominal, dispnéia e instabilidade cardiovascular. Realizou-se punção abdominal de emergência, o que determinou a melhora clínica da paciente até que laparotomia de urgência fosse realizada. Após laparotomia exploradora e sutura da perfuração a paciente evoluiu clinicamente bem.

CONCLUSÕES: O pinçamento por via endoscópica de perfuração intestinal secundária à colonoscopia pode contribuir para a formação de pneumoperitônio hipertensivo e síndrome de compartimento abdominal, com repercussões clínicas graves que exigem tratamento imediato. Profissionais capacitados e recursos técnicos adequados podem ser fatores determinantes do prognóstico do paciente.

\footnotetext{
${ }^{*}$ Recebido da Santa Casa de Belo Horizonte, MG

1. Título de Especialista em Terapia Intensiva; Anestesiologista da Santa Casa de BH e do Hospital das Clínicas da UFMG; Responsável pelo CET da Santa Casa de BH

2. Chefe do Serviço de Anestesiologia da Santa Casa de BH; Anestesiologista do Hospital da Unimed BH; Corresponsável pelo CET da Santa Casa de BH

3. Anestesiologista da Santa Casa de BH; Intensivista do Hospital Socor - BH

4. Anestesiologista da Santa Casa de BH
}

Apresentado (Submitted) em 19 de fevereiro de 2009

Aceito (Accepted) para publicação em 15 de junho de 2009

Endereço para correspondência (Correspondence to):

Dra. Magda Lourenço Fernandes

Rua Padre Marinho, 480/1206,

Santa Efigênia,

30140-040 Belo Horizonte, MG

e-mail: balourenco@hotmail.com
Unitermos: COMPLICAÇÕES: perfuração intestinal, pneumoperitôneo, síndrome de compartimento; EXAMES DIAGNÓSTICOS: colonoscopia; SEDAÇÃO: venosa.

\section{SUMMARY}

Fernandes ML, Pires KCC, Chimelli PHB, Issa MRN - Abdominal Compartment Syndrome during Endoscopic Clamping of an Intestinal Perforation Secondary to Colonoscopy.

BACKGROUND AND OBJECTIVES: Colonoscopy is widely used for diagnosis, treatment, and control of intestinal disorders. Intestinal perforation, although rare, is the most feared complication. Perforations can be treated by endoscopic clamping. The objective of this report was to alert specialists for the development and treatment of abdominal compartment syndrome during endoscopic clamping of an intestinal perforation secondary to colonoscopy.

CASE REPORT: This is a 60 years old female, physical status ASA II, who underwent colonoscopy under sedation. During the exam, an accidental intestinal perforation was observed, and it was decided to attempt the endoscopic clamping of the perforation. The patient developed abdominal pain and distension, pneumoperitoneum, abdominal compartment syndrome, dyspnea, and cardiovascular instability. Emergency abdominal puncture was done with clinical improvement until urgent laparotomy was performed. After exploratory laparotomy and stitching of the perforation, the patient presented good clinical evolution.

CONCLUSIONS: Endoscopic clamping of an intestinal perforation secondary to colonoscopy can contribute for the development of hypertensive pneumoperitoneum and abdominal compartment syndrome with severe clinical repercussions that demand immediate treatment. Capable professionals and adequate technical resources can be determinant of the prognosis of the patient.

Keywords: COMPLICATIONS: intestinal perforation, pneumoperitoneum, compartment syndrome; DIAGNOSTIC TESTS: colonoscopy; SEDATION: intravenous.

\section{INTRODUÇÃO}

A colonoscopia flexível é um exame amplamente utilizado nos dias atuais para diagnóstico, tratamento e controle de doenças intestinais, principalmente neoplasias ${ }^{1}$. Para conforto do paciente, este exame é feito sob sedação, realizada por médico anestesiologista. É um procedimento relativamente seguro, 


\section{Abdominal Compartment Syndrome During Endoscopic Clamping of an In- testinal Perforation Secondary to Colonoscopy}

Magda Lourenço Fernandes, TSA, M.D. ${ }^{1}$; Kleber Costa de Castro Pires, TSA, M.D. 2; Paulo Henrique Baumgratz Chimelli, M.D. ${ }^{3 ;}$ Márcia Rodrigues Neder Issa, M.D. ${ }^{4}$

\section{INTRODUCTION}

Flexible colonoscopy is widely used for diagnosis, treatment, and control of intestinal disorders especially neoplastic tumors ${ }^{1}$. It is performed under sedation with the assistance of an anesthesiologist. It is a relatively safe procedure with a low incidence of severe complications recorded in approximately $5 / 1,000$ procedures $^{1}$. Among them, intestinal perforation should be mentioned due to the high morbidity and mortality ${ }^{2}$. Fecal peritonitis, sepsis ${ }^{2}$, pneumoperitoneum, abdominal compartment syndrome (ACS), pneumomediastinum, subcutaneous emphysema, cardiovascular collapse, and cardiac arrest ${ }^{3}$ have been reported in association with intestinal perforation. Correction of the perforation can be conservative, surgical, or endoscopic ${ }^{2}$. Here we report a case of ACS with respiratory distress and cardiovascular instability during endoscopic clamping of an intestinal perforation secondary to colonoscopy.

\section{CASE REPORT}

This is a 60 years old female patient weighing $59 \mathrm{~kg}$, physical status ASA II, with hypothyroidism and depression, treated with levothyroxine and clonazepam. She had a history of two laparotomies, the first for appendicitis with peritonitis and the second for intra-abdominal adherences. She underwent elective diagnostic colonoscopy under sedation in a specialized clinic. Monitoring consisted of electrocardiograph, pulse oximeter, and non-invasive blood pressure. The patient was sedated with $100 \mu \mathrm{g}$ of fentanyl and $380 \mathrm{mg}$ of propofol administered as a bolus. She maintained spontaneous respiration with oxygen ( 3 L. $\left.\mathrm{min}^{-1}\right)$ via a nasal catheter. During the procedure accidental intestinal perforation was observed and the procedure continued in an attempt to clamp the perforation endoscopically. After approximately 20 minutes the patient developed pain, abdominal distension, cyanosis, and hypoperfusion of the lower limbs which were followed by sweating, tachycardia (120 bpm), arterial hypotension $(70 \mathrm{x}$ $50 \mathrm{mmHg}$ ), and moderate dyspnea and reduction in $\mathrm{O}_{2}$ saturation (90\%). Emergency abdominal puncture was performed, introducing two $14 \mathrm{G}$ catheters on the right abdominal flank. The patient showed partial improvement with increase in blood pressure $(110 \times 70 \mathrm{mmHg})$ and recovered respiratory pattern, and she was transferred to the hospital for an urgent laparotomy. On abdominal exploration, a perforation of the sigmoid colon that was repaired and abdominal adhesions were observed. The postoperative period was unremarkable and the patient was discharged from the hospital after two days.

\section{DISCUSSION}

Although rare, iatrogenic abdominal perforation during colonoscopy is seen in approximately $0.9 / 1,000$ procedures, ranging from 0.14 to $0.65 \%$, for diagnostic exams, and 0.15 to $3 \%$, for therapeutic exams ${ }^{1,2}$. Perforations are triggered by mixed mechanisms, including trauma, and mechanical, pneumatic, and therapeutic factors ${ }^{3,4}$. Inflammatory disease, diverticulum, history of pelvic radiotherapy, prior abdominal surgery ${ }^{3}$, advanced age, male gender, and polypectomy or endoscopy performed by a physician with little experience ${ }^{5}$ are some of the risk factors for perforations described in the literature. The sigmoid and cecum are affected more often$\mid y^{4,6}$. Abdominal pain and distension are the symptoms mostly seen ${ }^{4}$.

Intestinal perforation might not be associated with immediate clinical repercussions; however, the presence of large amounts of air in the peritoneal cavity can lead to fast and progressive increase in intra-abdominal pressure characterizing hypertensive pneumoperitoneum ${ }^{6}$. Abdominal compartment syndrome is used to describe clinical situations with abdominal distension, increased in abdominal pressure, inadequate ventilation, and renal dysfunction ${ }^{7}$. Although iatrogenic insufflation of the peritoneal cavity is not the main event in those situations, it can result in a clinical condition similar to that of ACS, and it has been described as such ${ }^{8}$. Besides respiratory changes, hypertensive pneumoperitoneum and ACS result in severe hemodynamic repercussions, such as decreased venous return, systolic volume, cardiac output, increased systemic vascular resistance, and increased intrathoracic pressure ${ }^{9}$. The air can also invade other cavities causing pneumoretroperitoneum, pneumomediastinum, pneumothorax, and subcutaneous emphysema in the face, neck, and thorax ${ }^{3,10}$.

A similar case to the one presented here, with severe hemodynamic repercussion, low cardiac output, and pulseless electrical activity was described in the postoperative period of an intestinal surgery ${ }^{8}$. However, the patient presented here did not have a history of recent surgery, but a history of intes- 
tinal adhesions and two surgeries. As mentioned before, prior abdominal surgery is a risk factor for intestinal perforation, which can result in the escape of air into the abdominal cavity and hypertensive pneumoperitoneum ${ }^{6}$. The endoscopic clamping of the perforation probably contributed for the development of pneumoperitoneum and its deleterious consequences since insufflation of air should be maintained during clamping ${ }^{11}$. Although recent studies suggest that endoscopic clamping of the perforation is a good therapeutic decision ${ }^{2,12}$, its technique and indications should be defined within rigid criteria ${ }^{2,11}$.

Abdominal compartment syndrome due to iatrogenic intestinal perforation evolving with respiratory distress and cardiovascular instability is a medical emergency and requires immediate measures. Treatment consists on abdominal decompression, and hemodynamic and respiratory support ${ }^{8}$. The procedure should be interrupted immediately and abdominal puncture with a large bore catheter should be performed. Depending on the severity of the case, tracheal intubation, volume infusion, and inotropic support might be necessary. In the case presented here, the patient showed immediate improvement after abdominal decompression and an immediate tracheal intubation or the use of amines were not necessary, but clinical vigilance and monitoring were maintained until laparotomy.

Adequate material resources, emergency equipment, and support hospital, as required by Resolution CFM number $1886 / 2008^{13}$ of the (Brazilian) medical federal board, are fundamental to guarantee a favorable outcome. Professionals involved should be attentive to risk factors and able to treat complications secondary to accidental intestinal perforation during a colonoscopy.

\section{REFERÊNCIAS - REFERENCES}

01. Levin TR, Zhao W, Conell C et al. - Complications of colonoscopy in an integrated health care delivery system. Ann Intern Med, 2006;145:880-886.

02. Putcha RV, Burdick JS - Management of iatrogenic perforation. Gastroenterol Clin North Am, 2003;32:1289-1309.

03. Ball CG, Kirkpatrick AW, Mackenzie S et al. - Tension pneumothorax secondary to colonic perforation during diagnostic colonoscopy: report of a case. Surg Today, 2006;36:478-480.

04. Garcia Martínez MT, Ruano Poblador A, Galan Raposo L et al. Perforation after colonoscopy: our 16-year experience. Rev Esp Enferm Dig 2007;99:588-592.

05. Rabeneck L, Paszat LF, Hilsden RJ et al. - Bleeding and perforation after outpatient colonoscopy and their risk factors in usual clinical practice. Gastroenterology, 2008;135:1899-1906.

06. Yokobi-Shvili R, Cheng D - Tension pneumoperitoneum. A complication of colonoscopy: recognition and treatment in the emergency department. J Emerg Med, 2002;22:419-420.

07. Ivatury RR, Diebel L, Porter JM et al. - Intra-abdominal hypertension and the abdominal compartment syndrome. Surg Clin North Am, 1997;77:783-800.
08. Peppriell JE, Bacon DR - Acute abdominal compartment syndrome with pulseless electrical activity during colonoscopy with conscious sedation. J Clin Anesth, 2000;12:216-219.

09. Schein M, Wittmann DH, Aprahamian CC et al. - The abdominal compartment syndrome: the physiological and clinical consequences of elevated intra-abdominal pressure. J Am Coll Surg, 1995;180:745-753.

10. Ignjatoviæ M, Joviæ J - Tension pneumothorax, pneumoretroperitoneum, and subcutaneous emphysema after colonoscopic polypectomy: a case report and review of the literature. Langenbecks Arch Surg, 2009:394:185-189.

11. Carr-Locke DL - The changing management of colonoscopyassociated. Digestion, 2008;78:216-217.

12. Magdeburg R, Collet $P$, Post $S$ et al. - Endoclipping of iatrogenic colonic perforation to avoid surgery. Surg Endosc, 2008;22: 1500-1504.

13. Brasil. Conselho Federal de Medicina. Resolução $n^{\circ} 1886$, de 13 de novembro de 2008. Dispõe sobre as Normas mínimas para o funcionamento de consultórios médicos e dos complexos cirúrgicos para procedimentos com internação de curta permanência. Diário Oficial da União; Poder Executivo, Brasília, DF, 21 nov. 2008. Seção I, p. 271-273.

\section{RESUMEN}

Fernandes ML, Pires KCC, Chimelli PHB, Issa MRN - Síndrome de Compartimiento Abdominal Durante Pinzamiento por Vía Endoscópica de Perforación Intestinal Secundaria a la Colonoscopia.

JUSTIFICATIVA Y OBJETIVOS: La colonoscopia es un examen utilizado muy a menudo en la actualidad para el diagnóstico, tratamiento y el control de las enfermedades intestinales. La perforación intestinal, aunque sea rara, es la más temida complicación de ese examen. La corrección de la perforación puede ser hecha a través del uso de clips introducidos por vía endoscópica. El objetivo de este relato de caso, fue avisarles a los expertos sobre el aparecimiento y el tratamiento del síndrome de Compartimiento Abdominal durante el pinzamiento endoscópico de perforación intestinal secundario a la colonoscopia.

RELATO DEL CASO: Paciente del sexo femenino, 60 años, estado físico ASA II, sometida a la colonoscopia bajo sedación. Durante el examen se comprobó la perforación accidental del intestino y se optó por tratar de pinzar la perforación por vía endoscópica. La paciente evolucionó con dolor y con una distensión abdominal, neumoperitoneo, síndrome de Compartimiento Abdominal, disnea e inestabilidad cardiovascular. Se realizó la punción abdominal de emergencia, lo que determinó la mejoría clínica de la paciente hasta que se hiciese la laparotomía de urgencia. Después de realizarla con exploración y con sutura de la perforación, la paciente evolucionó bien clínicamente.

CONCLUSIONES: El pinzamiento por vía endoscópica de perforación intestinal secundaria a la colonoscopia, puede contribuir a la formación de neumoperitoneo hipertensivo y el síndrome de Compartimiento Abdominal, con repercusiones clínicas graves que exigen un tratamiento inmediato. Los profesionales capacitados y los recursos técnicos adecuados, pueden ser factores determinantes del pronóstico del paciente. 